\title{
Glutathione Redox Cycle Protects Cultured Endothelial Cells against Lysis by Extracellularly Generated Hydrogen Peroxide
}

\author{
John M. Harlan, James D. Levine, Karleen S. Callahan, \\ and Barbara R. Schwartz \\ Department of Medicine (Hematology), University of \\ Washington, Seattle, Washington 98104
}

Laurence A. Harker

Scripps Clinic and Research Foundation, La Jolla, California 92037

A glutathione redox cycle as an antioxidant defense mechanism in cultured bovine and human endothelial cells by disrupting the glutathione redox cycle at several points. Endothelial glutathione reductase was selectively inhibited with 1,3-bis (chloroethyl)-1-nitrosourea (BCNU). Cellular stores of reduced glutathione were depleted by reaction with diethylmaleate (DEM) or 1-chloro-2,4-dinitrobenzene (CDNB) or by inhibition of glutathione synthesis with buthionine sulfoximine (BSO). Whereas several strains of untreated bovine and human endothelial cells were resistant to lysis by enzymatically generated hydrogen peroxide, BCNU-treated cells were readily lysed in a timeand dose-dependent manner. Glucose-glucose oxidasemediated lysis of BCNU-treated bovine endothelial cells was catalase-inhibitable and directly related to BCNU concentration and endogenous glutathione reductase activity. Pretreatment of bovine endothelial cells with BCNU did not potentiate lysis by distilled water, calcium ionophore, lipopolysaccharide, or hypochlorous acid. Depletion of cellular reduced glutathione by reaction with

This work was performed during the tenure of a Clinician Scientist Award of the American Heart Association (Dr. Harlan), with funds contributed in part by the American Heart Association of Washington. Address reprint requests to Dr. Harlan, Harborview Medical Center, Division of Hematology ZA-34, Seattle, WA 98104. Dr. Levine's current address is Boston VA Medical Center, Division of Hematology, Boston MA 02130

Received for publication 13 June 1983 and in revised form 18 No vember 1983.

J. Clin. Invest.

(c) The American Society for Clinical Investigation, Inc.

0021-9738/84/03/0706/08 $\$ 1.00$

Volume 73, March 1984, 706-713

DEM or CDNB or by inhibition of glutathione synthesis by BSO also potentiated endothelial lysis by enzymatically generated hydrogen peroxide. Inhibition of endothelial glutathione reductase by $\mathrm{BCNU}$ or depletion of reduced glutathione by BSO increased endothelial susceptibility to lysis by hydrogen peroxide generated by phorbal myristate acetate-activated neutrophils. We conclude that the glutathione redox cycle plays an important role as an endogenous antioxidant defense mechanism in cultured endothelial cells.

\section{Introduction}

Cells may detoxify hydrogen peroxide $\left(\mathrm{H}_{2} \mathrm{O}_{2}\right)$ by catalase or the glutathione peroxidase-glutathione reductase system. In tumor cells, susceptibility to lysis by either neutrophil- or macrophagegenerated $\mathrm{H}_{2} \mathrm{O}_{2}$ varies considerably and, in some, is dependent on the activity of the glutathione redox cycle but not catalase (1). The glutathione redox cycle is also important in protecting normal cells from oxidant injury (2-4).

In the glutathione redox cycle the oxidation of reduced glutathione by $\mathrm{H}_{2} \mathrm{O}_{2}$ is catalyzed by glutathione peroxidase. The oxidized glutathione is then reconverted to reduced glutathione by glutathione reductase. The glutathione redox cycle can be disrupted at several points in vitro (4) (Fig. 1). Glutathione reductase may be selectively inhibited by 1,3-bis (chloroethyl)1-nitrosourea $(\mathrm{BCNU})^{1}(1,5,6)$. Cellular stores of reduced glutathione can be depleted by formation of a thioether conjugate with electrophilic agents such as 1-chloro-2,4-dinitrobenzene

1. Abbreviations used in this paper: $\mathrm{BCNU}, 1,3-$ bis (chloroethyl)-1-nitrosourea; BSO, buthionine sulfoximine; CDNB, 1-chloro-2,4-dinitrobenzene; DEM, diethylamaleate; $\mathrm{H}_{2} \mathrm{O}_{2}$, hydrogen peroxide; LPS, lipopolysaccharide; NBCS, newborn calf serum; PMA, phorbol myristate acetate; ${ }^{\text {sl }} \mathrm{Cr}$, sodium chromate. 


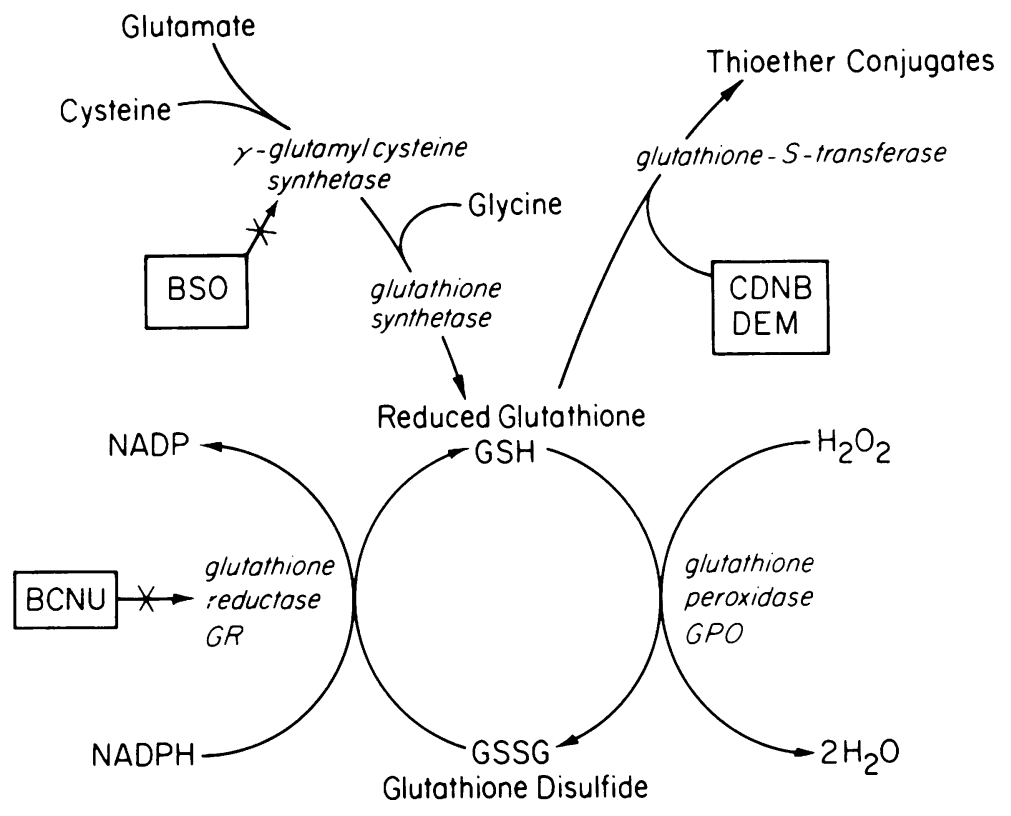

Figure 1. Pharmacologic modification of the glutathione redox cycle in vitro.
(CDNB) $(7,8)$ or diethylmaleate $(\mathrm{DEM})(9-11)$ in a reaction catalyzed by endogenous glutathione-s-transferase. After cleavage of the $\gamma$-glutamyl and glycinyl moieties of the glutathione and acetylation of the cysteine, the resulting mercapturic acid is excreted. Glutathione biosynthesis may be inhibited by buthionine sulfoximine (BSO), a selective inhibitor of $\gamma$-glutamylcysteine synthetase $(4,8,11,12)$.

We have examined the role of the glutathione redox cycle in modulating oxidant injury to endothelial cells in culture by disrupting the glutathione redox cycle at several points. Endothelial cell glutathione reductase was selectively inhibited with BCNU and cellular stores of reduced glutathione were depleted by reaction with CDNB or DEM or by inhibition of glutathione synthesis with BSO.

\section{Methods}

Preparation of endothelial cells. Bovine aortic and pulmonary artery and human umbilical vein endothelial cells were obtained as previously described $(13,14)$ and cultured in Waymouth's medium MB-752/1 (Grand Island Biological Co. [Gibco], Grand Island, NY) supplemented with $10 \%$ newborn calf serum (NBCS) (Gibco). Bovine endothelial cells were used in 6th-15th passage. Because bovine endothelial cell susceptibility to lysis by the toxic agents varied somewhat between strains and passage number within the same strain, individual experiments were always performed with cells of the same strain and passage. Human umbilical vein endothelial cells were used in first or second passage only.

Neutrophil preparation. Purified human peripheral neutrophils were prepared by the standard technique of Ficoll-Hypaque gradient centrifugation, dextran sedimentation, and hypotonic lysis of erythrocytes (15)

${ }^{5 l}$ Chromium-release assay. Endothelial cells were plated on Falcon Microtest III plates (Falcon Labware, Div. of Becton-Dickinson \& Co.,
Oxnard, CA) and labeled with sodium chromate $\left({ }^{51} \mathrm{Cr}\right.$ ) (New England Nuclear, Boston, MA) as previously described (16). In some experiments endothelial cells were incubated with BSO during the overnight labeling. After overnight incubation, cells were washed three times with $1 \%$ NBCS in phosphate-buffered saline (PBS) (Gibco) and then incubated with either BCNU, DEM, CDNB, or ethanol control in 10\% NBCS in Waymouth's medium. Endothelial cells were incubated with BCNU for 10 min, after which they were washed twice with $1 \%$ NBCS in PBS. Endothelial cells were incubated with DEM and CDNB for 30-60 min without further washing. Test or control medium was then added to a final volume of $100-200 \mu \mathrm{l} /$ well, and the cells were incubated at $37^{\circ} \mathrm{C}$ in a $95 \%$ air and $5 \% \mathrm{CO}_{2}$ atmosphere. $50-100 \mu \mathrm{l}$ of cell-free supernatant medium was removed at intervals for determination of specific ${ }^{51} \mathrm{Cr}$ release as follows: $(A-B / C-B) \times 100 \%$. A represents the mean test ${ }^{51} \mathrm{Cr}$-cpm released, B represents the mean spontaneous ${ }^{51} \mathrm{Cr}$-cpm released, and $\mathrm{C}$ represents the mean maximum ${ }^{\mathrm{S}} \mathrm{Cr}$-cpm released. Maximum ${ }^{51} \mathrm{Cr}$-release was determined by incubation in $1 \%$ Triton X-100 (New England Nuclear). Spontaneous ${ }^{51} \mathrm{Cr}$-release was determined in control monolayers incubated in 10\% NBCS in Waymouth's medium only and was $10-15 \%$ of maximum ${ }^{51} \mathrm{Cr}$-release after $6 \mathrm{~h}$ of incubation. Statistical significance was determined by comparing mean test and mean control ${ }^{51} \mathrm{Cr}$-cpm released by two-tailed, unpaired, $t$-statistic.

For neutrophil experiments $50 \mu \mathrm{l}$ of neutrophils in 10\% NBCS in Waymouth's medium was added and allowed to adhere to the endothelial monolayer for $10 \mathrm{~min}$ before addition of $50 \mu \mathrm{l}$ of medium with or without phorbol myristate acetate (PMA).

Enzyme assays. Duplicate $25-\mathrm{cm}^{2}$ flasks of $\mathrm{BCNU}$-treated or ethanol $(0.1 \%)$ control endothelial cells $\left(2-3 \times 10^{6}\right.$ cells $)$ were solubilized by incubation with $0.2 \%$ Triton $\mathrm{X}-100$ at room temperature for $1 \mathrm{~h}$, frozen at $-80^{\circ} \mathrm{C}$, and the supernatant medium was assayed for glutathione reductase activity and catalase by Dr. Ernest Beutler of the Scripps Clinic and Research Foundation, La Jolla, CA (17). Recovery of glutathione reductase activity after a $1-\mathrm{h}$ incubation in $0.2 \%$ Triton X-100 at room temperature and subsequent storage at $-80^{\circ} \mathrm{C}$ for several weeks was $100 \%$. Reduced soluble sulfhydryl content was measured in DEM-, CDNB-, BSO-treated, and control endothelial cells as follows $(8,18$, 
19). Duplicate $75-\mathrm{cm}^{2}$ flasks of endothelial cells $\left(5-10 \times 10^{6}\right.$ cells) of the same strain and passage were incubated with control medium, DEM $(0.5 \mathrm{mM}), \mathrm{CDNB}(10 \mu \mathrm{M})$, or BSO $(1 \mathrm{mM})$. After incubation the flasks were washed three times with $0.02 \%$ EDTA in PBS and the cells harvested with $0.05 \%$ trypsin and $0.02 \%$ EDTA in PBS buffer. An aliquot was then removed for determination of cell count by electronic counter (Particle Data, Inc., Elmhurst, IL). After centrifugation at $200 \mathrm{~g}$ for 10 min, the cell pellets were resuspended in $1.4 \mathrm{ml}$ of $0.2 \%$ Triton X-100 and $2.5 \%$ sulfosalicylic acid in EDTA/PBS buffer. Solutions were cleared by centrifugation at $11,000 \mathrm{~g}$ for $5 \mathrm{~min}$. A $1.0-\mathrm{ml}$ aliquot of the acidsoluble supernatant medium was then added to $2.0 \mathrm{ml}$ of $0.3 \mathrm{M} \mathrm{Na}_{2}$ $\mathrm{HPO}_{4}$ buffer. Spectrophotometric determinations were performed with a Gilford 300-N spectrophotometer (Gilford Instruments Laboratories, Inc., Oberlin, $\mathrm{OH}$ ) at $412 \mathrm{~nm}$ immediately after the addition of 0.25 $\mathrm{ml}$ of 5,5-dithiobis-2-nitrobenzoic acid $(40 \mathrm{mg} / \mathrm{dl}$ in $1 \%$ sodium citrate) (20). With each assay a standard curve was generated with known amounts of reduced glutathione $(5-100 \mathrm{nmol})$. Recovery of reduced glutathione added at the time of cell lysis was $>90 \%$. Results are expressed as nanomoles of soluble reduced sulfhydryls $/ 10^{6}$ endothelial cells.

Reagents. Catalase (11,800 U/mg protein), bovine serum albumin, reduced glutathione, glutathione reductase, 5,5-dithiobis-2-nitrobenzoic acid, superoxide dismutase $(2,700 \mathrm{U} / \mathrm{mg}$ protein), glucose oxidase VII, xanthine oxidase gr. I, 5-sulfosalicylic acid, xanthine, hydrogen peroxide (30\%), Escherichia coli 055:B5 lipopolysaccharide (LPS), and PMA were obtained from Sigma Chemical Co., St. Louis, MO. Trypan blue dye was obtained from Gibco. Sodium hypochlorite solution was obtained from Scientific Products, Redmond, WA and was standardized by reaction with $\mathrm{KI}$ and spectrophotometric measurement of $\mathrm{I}_{3}^{-}$formed using $E_{353}=2.64 \times 10^{4} \mathrm{M}^{-1} \mathrm{~cm}^{-1}(21)$. BCNU was obtained from Bristol Laboratories Div., Bristol-Meyers Co., Syracuse, NY and dissolved in ethanol at a $100-\mathrm{mg} / \mathrm{ml}$ stock just before each experiment. CDNB and DEM were obtained from Sigma Chemical Co., and dissolved in ethanol as $10^{-2}$ - and $1-\mathrm{M}$ stocks just before use. DL-buthionine-SR-sulfoximine was obtained from Chemalog, Div. of Chemical Dynamics Corporation, South Plainfield, NJ and dissolved in medium of $10^{-2} \mathrm{M}$. The calcium ionophore, A23187, was obtained from Calbiochem-Behring Corp., La Jolla, CA and dissolved in dimethyl sulfoxide at $5 \times 10^{-2} \mathrm{M}$.

\section{Results}

Effect of $B C N U$ on endothelial cell lysis by enzymatically generated $\mathrm{H}_{2} \mathrm{O}_{2}$. Pretreatment of bovine pulmonary artery endothelial cells with BCNU $(100 \mu \mathrm{g} / \mathrm{ml})$ increased their susceptibility to lysis by both the $\mathrm{H}_{2} \mathrm{O}_{2}$-generating system, glucose-glucose oxidase, and the superoxide anion-generating system, xanthinexanthine oxidase (Table I $A$ ). Pretreatment with BCNU alone $(100 \mu \mathrm{g} / \mathrm{ml}$ for $10 \mathrm{~min})$ did not significantly increase endothelial cell ${ }^{51} \mathrm{Cr}$-release at $6 \mathrm{~h}$ compared with ethanol control. Although the susceptibility of untreated bovine pulmonary artery and aortic endothelial cells to glucose-glucose oxidase-mediated lysis varied somewhat between strains and passage number within the same strain, pretreatment with $\mathrm{BCNU}$ always potentiated $\mathrm{H}_{2} \mathrm{O}_{2}$-mediated lysis when assessed in a dose-response assay (Fig. 2). As with bovine endothelial cells, BCNU also significantly increased the susceptibility of human umbilical vein endothelial cells to lysis by enzymatically generated $\mathrm{H}_{2} \mathrm{O}_{2}$ (Fig. 3), whereas $\mathrm{BCNU}$ alone did not significantly increase ${ }^{51} \mathrm{Cr}$-release. Both glucose-glucose oxidase- and xanthine-xanthine oxidase-me-
Table I. Effect of BCNU on Bovine Endothelial Cell Lysis by Oxygen Radical-generating Systems

\begin{tabular}{llr}
\hline & \multicolumn{2}{c}{ \% Specific ${ }^{\text {s1 }}$ Cr-release } \\
\cline { 2 - 3 } & \multicolumn{2}{c}{ Pretreatment with } \\
\cline { 2 - 3 } & \multicolumn{1}{c}{$\begin{array}{l}\text { Ethanol } \\
\text { control }\end{array}$} \\
Addition to endothelial monolayer & \multicolumn{1}{c}{ BCNU } \\
\hline A Bovine pulmonary artery & & \\
Glucose-glucose oxidase (4) & $1.0 \pm 0.1$ & $76.9 \pm 6.9$ \\
+ Catalase (4) & $1.1 \pm 0.2$ & $3.3 \pm 2.3$ \\
Xanthine-xanthine oxidase (4) & $0.8 \pm 0.1$ & $14.1 \pm 2.4$ \\
+ Catalase (4) & $0.2 \pm 0.1$ & $2.3 \pm 1.1$ \\
+ Superoxide dismutase (4) & $0.2 \pm 0.1$ & $12.8 \pm 1.5$ \\
B Bovine aortic & & \\
Glucose-glucose oxidase (6) & $16.2 \pm 0.9$ & $61.2 \pm 1.7$ \\
+ Catalase (6) & $0.4 \pm 0.1$ & $1.0 \pm 0.1$ \\
+ Catalase boiled (6) & $17.3 \pm 2.4$ & $54.9 \pm 2.7$
\end{tabular}

Glucose $(27 \mathrm{mM})$ and glucose oxidase $(10 \mathrm{mU} / \mathrm{ml})$ or xanthine $\left(10^{-5}\right.$ M) and xanthine oxidase $(100 \mathrm{mU} / \mathrm{ml})$ with or without catalase $(3,000 \mathrm{U} / \mathrm{ml})$, catalase boiled for $20 \mathrm{~min}$ before, or superoxide dismutase $(270 \mathrm{U} / \mathrm{ml})$ were added to ${ }^{51} \mathrm{Cr}$-labeled bovine pulmonary artery $(A)$ or aortic $(B)$ endothelial cells that were preincubated for 10 min with BCNU $(100 \mu \mathrm{g} / \mathrm{ml})$ or ethanol control $(0.1 \%) .{ }^{51} \mathrm{Cr}$-release was determined at $4 \mathrm{~h}$ by aspirating and counting 50- $\mu \mathrm{l}$ aliquots of the cell-free supernatant medium. Values represent the means of $(n)$ replicates $\pm 1 \mathrm{SE}$.

diated lysis of BCNU-treated cells were inhibited by catalase but not by superoxide dismutase (Table I $A$ ). Inhibition of endothelial lysis by catalase was due to its enzymatic activity, since boiled catalase was without protective effect (Table I $B$ ). Glucoseglucose oxidase-mediated bovine endothelial ${ }^{51} \mathrm{Cr}$-release was associated with trypan blue dye uptake, indicating that endothelial cell lysis had occurred; in a 4-h incubation with glucose $(27 \mathrm{mM})$-glucose oxidase $(10 \mathrm{mU} / \mathrm{ml})$, the specific ${ }^{51} \mathrm{Cr}$-release from BCNU-treated aortic endothelial cells was $58.2 \pm 1.4 \%$ and trypan blue dye uptake was $57.4 \pm 4.5 \%$ (means of four replicates $\pm 1 \mathrm{SE})$.

Time course of $\mathrm{H}_{2} \mathrm{O}_{2}$-mediated endothelial lysis. Incubation with glucose-glucose oxidase did not induce significant ${ }^{51} \mathrm{Cr}$ release until relatively late (3-4 h), even in BCNU-treated cells (Fig. 4). Despite the absence of specific ${ }^{51} \mathrm{Cr}$-release in the first several hours of exposure to glucose-glucose oxidase, significant specific ${ }^{51} \mathrm{Cr}$-release was observed at $6 \mathrm{~h}$ in endothelial cells exposed to the $\mathrm{H}_{2} \mathrm{O}_{2}$-generating system for only $1-2 \mathrm{~h}$ before addition of catalase (Fig. 5).

Glutathione reductase activity in BCNU-treated endothelial cells. Fig. 6 demonstrates that both bovine endothelial glutathione reductase activity and glucose-glucose oxidase-induced lysis were directly correlated with the concentration of BCNU. More importantly, bovine endothelial susceptibility to lysis by $\mathrm{H}_{2} \mathrm{O}_{2}$ was inversely related to endogenous glutathione reductase 


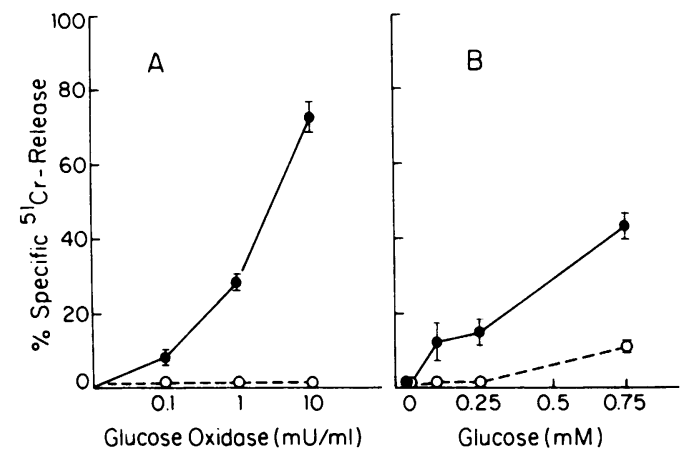

Figure 2. Dose-dependence of glucose-glucose oxidase-induced bovine endothelial ${ }^{51} \mathrm{Cr}$-release. Bovine aortic endothelial cells of two different strains $(A$ and $B)$ were labeled overnight with ${ }^{51} \mathrm{Cr}$, washed, and preincubated for 10 min with ethanol control $(0.1 \%)(0)$ or BCNU (100 $\mu \mathrm{g} / \mathrm{ml})(\bullet)$. The cells were washed again and then incubated with $(A) 10 \%$ NBCS in Waymouth's medium or (B) $0.25 \%$ bovine serum albumin in PBS without glucose. In $A$ the concentration of glucose was $27 \mathrm{mM}$ and in $B$ the concentration of glucose oxidase was $5 \mathrm{mU} / \mathrm{ml}$. Aliquots of supernatant medium were removed after $4 \mathrm{~h}$ of incubation for determination of specific ${ }^{51} \mathrm{Cr}$-release. Values represent means of six replicates \pm 1 SE.

activity (Fig. 6). BCNU also markedly reduced human umbilical vein endothelial glutathione reductase activity $(1.0 \mathrm{mIU} / \mathrm{mg}$ protein after a 10-min incubation with BCNU $100 \mu \mathrm{g} / \mathrm{ml} \mathrm{com-}$ pared with $13.0 \mathrm{mIU} / \mathrm{mg}$ protein in $0.1 \%$ ethanol control). Endogenous catalase levels in the bovine endothelial cells were not affected by a $10-\mathrm{min}$ incubation with $100 \mu \mathrm{g} / \mathrm{ml} \mathrm{BCNU} \mathrm{(5.1}$ and $6.2 \mathrm{IU} / \mathrm{mg}$ protein in control cells compared with 5.1 and $14.6 \mathrm{IU} / \mathrm{mg}$ protein in BCNU-treated bovine aortic endothelial cells).

Specificity of $\mathrm{BCNU}$ for $\mathrm{H}_{2} \mathrm{O}_{2}$-mediated injury in bovine endothelial cells. Bovine aortic endothelial cell susceptibility to lysis by distilled water, calcium ionophore, and LPS was not affected by pretreatment with $\mathrm{BCNU}$, despite $\mathrm{BCNU}$ potentiation of ${ }^{51} \mathrm{Cr}$-release by enzymatically generated $\mathrm{H}_{2} \mathrm{O}_{2}$ in the same cells (Table II). Moreover, BCNU did not potentiate en-

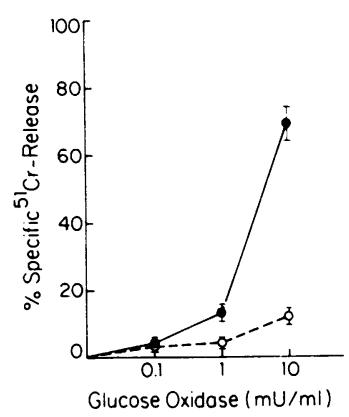

Figure 3. Dose-dependence of glucose-glucose oxidase-induced human endothelial cell ${ }^{51} \mathrm{Cr}$-release. Human umbilical vein endothelial cells were labeled overnight with ${ }^{51} \mathrm{Cr}$, washed, and preincubated for $10 \mathrm{~min}$ with ethanol control $(0.1 \%)(0)$ or $\mathrm{BCNU}$ $(100 \mu \mathrm{g} / \mathrm{ml})(\bullet)$. The cells were again washed and then incubated with glucose $(27 \mathrm{mM})$ and glucose oxidase. Aliquots of supernatant medium were removed after $6 \mathrm{~h}$ of incubation for

determination of specific ${ }^{51} \mathrm{Cr}$-release. Values represent means of eight replicates $\pm 1 \mathrm{SE}$.

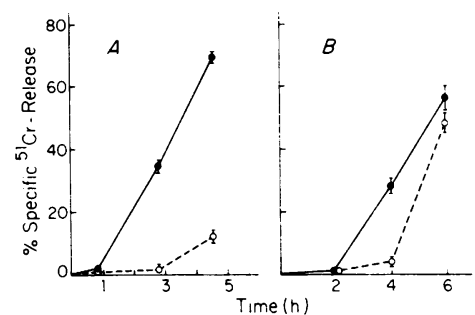

Figure 4. Time course of glucose-glucose oxidase-induced bovine endothelial ${ }^{51} \mathrm{Cr}$-release. Bovine aortic endothelial cells of two different strains ( $A$ and $B$ ) were labeled overnight with ${ }^{51} \mathrm{Cr}$, washed, and preincubated for 10 min with

ethanol control $(0.1 \%)(0)$ or BCNU $(100 \mu \mathrm{g} / \mathrm{ml})(\bullet)$. The cells were washed again and then incubated with glucose $(27 \mathrm{mM})$ and glucose oxidase ( $10 \mathrm{mU} / \mathrm{ml}$ in $A$ and $25 \mathrm{mU} / \mathrm{ml}$ in $B$ ). Aliquots of supernatant medium were sampled for determination of specific ${ }^{51} \mathrm{Cr}$-release at various intervals. Values represent means of eight replicates \pm 1 SE.

dothelial lysis by the oxidizing agent, hypochlorous acid (Fig. $7 \mathrm{~B}$ ), whereas it markedly increased bovine endothelial susceptibility to lysis by reagent $\mathrm{H}_{2} \mathrm{O}_{2}$ (Fig. $7 \mathrm{~A}$ ).

Effect of glutathione depletion of $\mathrm{H}_{2} \mathrm{O}_{2}$-mediated endothelial cell lysis. Since glutathione accounts for the majority of solublereduced sulfhydryls in cells (22), reduced glutathione levels in endothelial cells were determined by measuring total solublereduced sulfhydryl content without identifying the individual species of sulfhydryls.

Incubation of bovine aortic endothelial cells with CDNB $(10 \mu \mathrm{M})$ produced a $68 \%$ reduction in soluble-reduced sulfhydryl content at $1 \mathrm{~h}\left(1.3\right.$ and $1.6 \mathrm{nmol} / 10^{6}$ cells in CDNB-treated cells compared with 4.4 and $4.6 \mathrm{nmol} / 10^{6}$ cells in ethanol control) without significantly increasing ${ }^{51} \mathrm{Cr}$-release $\left(0 \%\right.$ specific ${ }^{51} \mathrm{Cr}$ release in CDNB-treated cells at $6 \mathrm{~h}$ ). Incubation with CDNB significantly increased bovine aortic endothelial cell susceptibility to glucose-glucose oxidase-mediated lysis (Fig. 8).

The soluble reduced sulfhydryl content of human umbilical vein endothelial cells incubated with DEM $(0.5 \mathrm{mM})$ for $1 \mathrm{~h}$ was reduced $60 \%$ compared with ethanol control (4.1 and 3.4 $\mathrm{nmol} / 10^{6}$ cells with DEM compared with 9.0 and $9.6 \mathrm{nmol} /$ $10^{6}$ cells in ethanol control). Although DEM $(0.5 \mathrm{mM})$ alone did not produce significant ${ }^{51} \mathrm{Cr}$-release $\left(<5 \%\right.$ specific ${ }^{51} \mathrm{Cr}$-release at $6 \mathrm{~h}$ ), incubation of human umbilical vein endothelial cells

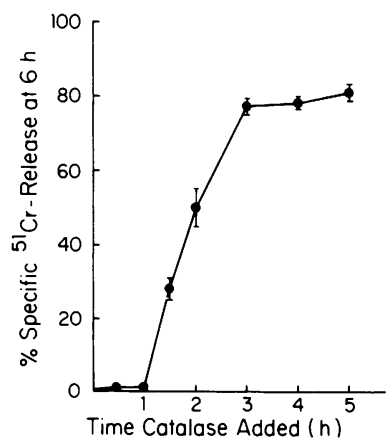

Figure 5. Effect of the duration of initial exposure to glucose-glucose oxidase on subsequent ${ }^{51} \mathrm{Cr}$-release. Bovine aortic endothelial cells were labeled overnight with ${ }^{51} \mathrm{Cr}$, washed, and preincubated with BCNU $(100 \mu \mathrm{g} / \mathrm{ml})$. The cells were washed again and then incubated with glucose $(27 \mathrm{mM})$ and glucose oxidase $(25 \mathrm{mU} / \mathrm{ml})$. Catalase $(3,000 \mathrm{U} / \mathrm{ml})$ was added at various time points and aliquots of supernatant medium were sam-

pled at $6 \mathrm{~h}$ for determination of specific ${ }^{51} \mathrm{Cr}$-release. Values represent means of eight replicates \pm 1 SE. 


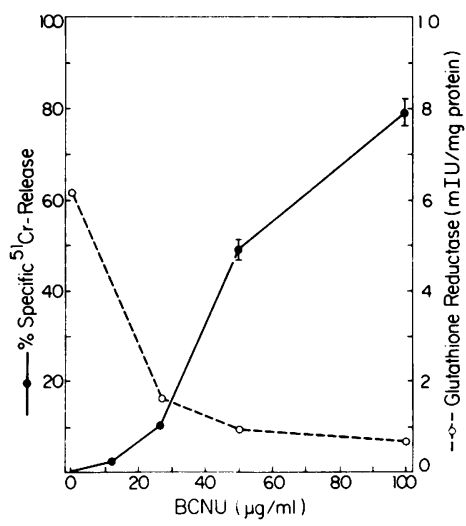
lease (๑) was determined after incubation with glucose $(27 \mathrm{mM})$ and glucose oxidase $(10 \mathrm{mU} / \mathrm{ml})$ for $4 \mathrm{~h}$. Glutathione reductase activity (o) was determined in Triton-solubilized cells. Values for ${ }^{51} \mathrm{Cr}$-release represent means of eight replicates $\pm 1 \mathrm{SE}$. The glutathione reductase levels are the average of duplicate $25-\mathrm{cm}^{2}$ flasks.

with DEM increased their susceptibility to glucose-glucose oxidase-mediated lysis (Fig. 9).

In concentrations up to $10 \mathrm{mM}$ for $48 \mathrm{~h}$, BSO was not toxic to human umbilical vein endothelial cells as assessed by phasecontrast microscopy and trypan blue dye exclusion. ${ }^{51} \mathrm{Cr}$ uptake during overnight labeling and spontaneous release during a subsequent 6-h incubation were also unaffected by BSO (1 mM). In contrast to tumor cells where incubation with BSO produced $>90 \%$ reduction in reduced glutathione levels $(8,11)$, incubation of human endothelial cells with BSO $(1 \mathrm{mM})$ for $18 \mathrm{~h}$ produced only a $61 \%$ decrease in the soluble reduced sulfhydryl content $\left(3.8 \pm 0.5 \mathrm{nmol} / 10^{6}\right.$ cells in BSO-treated cells compared to $10.6 \pm 2.9 \mathrm{nmol} / 10^{6}$ cells in control cells, means of three replicate flasks $\pm 1 \mathrm{SD}$ ). Increasing the concentration of BSO to $10 \mathrm{mM}$

Table II. Effect of BCNU on Bovine Endothelial Lysis by Nonoxidant Agents

\begin{tabular}{llr}
\hline & \multicolumn{2}{c}{$\%$ Specific ${ }^{\text {s1 }}$ Cr-release } \\
\cline { 2 - 3 } & \multicolumn{2}{c}{ Pretreatment with } \\
\cline { 2 - 3 } Addition to endothelial monolayer & \multicolumn{1}{c}{ Ethanol control } & \multicolumn{1}{c}{ BCNU } \\
\hline Distilled water & $28.3 \pm 2.8$ & $27.2 \pm 1.1$ \\
A23187 & $54.4 \pm 2.2$ & $22.2 \pm 2.2$ \\
LPS & $5.1 \pm 1.7$ & $5.4 \pm 1.1$ \\
Glucose-glucose oxidase & $8.2 \pm 1.0$ & $31.2 \pm 2.3$
\end{tabular}

${ }^{51} \mathrm{Cr}$-labeled bovine aortic endothelial cell monolayers were preincubated for 10 min with BCNU $(100 \mu \mathrm{g} / \mathrm{ml})$ or ethanol control $(0.1 \%)$. Specific ${ }^{51} \mathrm{Cr}$-release was determined after a 4-h incubation with distilled water, A23187 $(50 \mu \mathrm{M})$, LPS $(100 \mu \mathrm{g} / \mathrm{ml})$, or glucose $(27 \mathrm{mM})$ glucose oxidase $(4 \mathrm{mU} / \mathrm{ml})$. Values represent the means of eight replicates $\pm 1 \mathrm{SE}$.

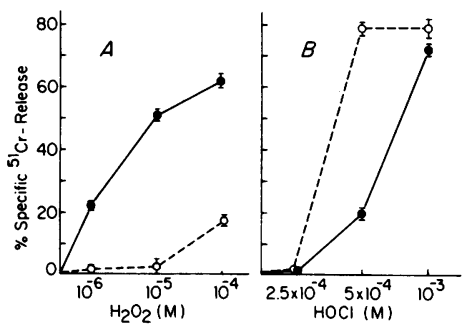

Figure 7. Specificity of BCNU for $\mathrm{H}_{2} \mathrm{O}_{2}$-mediated endothelial cell lysis. Bovine aortic endothelial cells of the same strain and passage were labeled overnight with ${ }^{51} \mathrm{Cr}$, washed, and preincubated for $10 \mathrm{~min}$ with $0.1 \%$ ethanol control (0) or BCNU $(100 \mu \mathrm{g} / \mathrm{ml})$

(๑). The cells were washed again and then incubated with reagent $\mathrm{H}_{2} \mathrm{O}_{2}(A)$ or $\mathrm{HOCl}(B)$. After a 4-h incubation, $50 \mu$ l of supernatant medium were aspirated for determination of specific ${ }^{51} \mathrm{Cr}$-release. Values represent means of six replicates $\pm 1 \mathrm{SE}$.

did not cause further reduction in human endothelial reduced glutathione at $18 \mathrm{~h}$. The failure of BSO to produce a greater depletion of human endothelial-reduced glutathione may be due to slower turnover of reduced glutathione in the confluent endothelial cells. Nevertheless, depletion of reduced glutathione by inhibition of its synthesis with BSO significantly increased human umbilical vein endothelial cell sensitivity to glucoseglucose oxidase-mediated lysis (Fig. 10).

Role of glutathione redox cycle in the neutrophil-mediated lysis of endothelial cells. PMA-activated neutrophils failed to induce significant ${ }^{51} \mathrm{Cr}$-release from untreated human or bovine endothelial monolayers. If the endothelial glutathione redox cycle was disrupted by pretreatment with BCNU, however, significant catalase-inhibitable lysis was observed (Table III). Depletion of endothelial reduced glutathione by inhibition of glutathione synthesis by BSO also significantly increased endothelial susceptibility to lysis by PMA-activated neutrophils (Fig. 11).

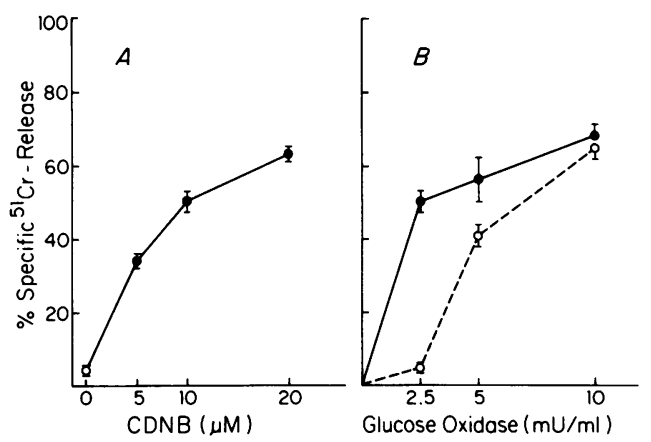

Figure 8. Effect of CDNB on glucose-glucose oxidase-induced bovine endothelial ${ }^{51} \mathrm{Cr}$-release. Bovine aortic endothelial cells of the same strain and passage were labeled overnight with ${ }^{51} \mathrm{Cr}$, washed, and preincubated for 30 min with ethanol control $(0.1 \%)(0)$ or CDNB (๑). Glucose (27 $\mathrm{mM})$ and glucose oxidase were then added without further washing. In $A$ the concentration of glucose oxidase was 2.5 $\mathrm{mU} / \mathrm{ml}$. In $B$ the concentration of CDNB was $10 \mu \mathrm{M}$. After $6 \mathrm{~h}$, aliquots of supernatant medium were aspirated for determination of specific ${ }^{51} \mathrm{Cr}$-release. Values represent means of six replicates $\pm 1 \mathrm{SE}$. 

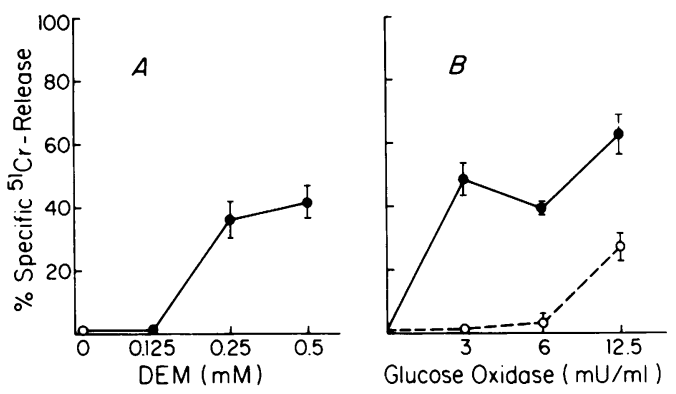

Figure 9. Effect of DEM on glucose-glucose oxidase-induced human endothelial ${ }^{51} \mathrm{Cr}$-release. Human umbilical vein endothelial cells from two different isolates $(A$ and $B)$ were labeled overnight with ${ }^{51} \mathrm{Cr}$, washed, and preincubated for $30 \mathrm{~min}$ with ethanol control $(0.1 \%)(0)$ or DEM (๑). Glucose $(27 \mathrm{mM})$ and glucose oxidase were then added without further washing. In $A$ the concentration of glucose oxidase was $25 \mathrm{mU} / \mathrm{ml}$. In $B$ the concentration of DEM was $0.5 \mathrm{mM}$. After $6 \mathrm{~h}$, aliquots of supernatant medium were aspirated for determination of specific ${ }^{51} \mathrm{Cr}$-release. Values represent means of six replicates $\pm 1 \mathrm{SE}$.

\section{Discussion}

In our previous studies of neutrophil-mediated endothelial cell injury we were unable to demonstrate significant human endothelial cell lysis by serum-treated zymosan-activated neutrophils (16). These results were in contrast to those of Sacks et al. (23) who observed small amounts of catalase-inhibitable ${ }^{51} \mathrm{Cr}$ release by complement- and zymosan-activated neutrophils, and Weiss et al. (24) who found significant catalase-inhibitable ${ }^{51} \mathrm{Cr}$-release with prolonged exposure to PMA-activated, but not zymosan-activated, neutrophils. These discrepancies in experimental results may relate in part to methodologic differences in the assays employed, but might also reflect differences in endogenous antioxidant defense mechanisms in cultured cells. Recently, Hoover et al. also failed to observe endothelial lysis by PMA-activated neutrophils and noted that neutrophil superoxide anion production was apparently reduced when neutrophils were in contact with endothelial monolayers, suggesting

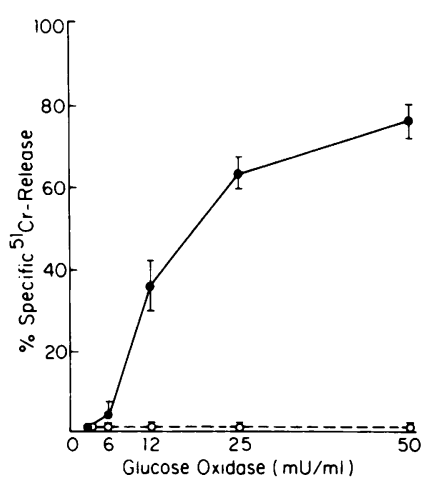

Figure 10. Effect of BSO on glucose-glucose oxidase-induced human endothelial cell ${ }^{51} \mathrm{Cr}$-release. Human umbilical vein endothelial cells were labeled overnight with ${ }^{51} \mathrm{Cr}$ in $10 \%$ NBCS in Waymouth's medium with $(\bullet)$ or without (o) BSO (1 mM). The cells were then washed and $10 \%$ NBCS in Waymouth's medium with or without BSO (1 mM) was added, followed by glucose oxidase. After $4 \mathrm{~h}$, aliquots of

supernatant medium were removed for determination of specific

${ }^{51} \mathrm{Cr}$-release. Values represent means of six replicates $\pm 1 \mathrm{SE}$.
Table III. Effect of BCNU on Bovine and Human Endothelial Cell Lysis by PMA-activated Neutrophils

\begin{tabular}{llr}
\hline & \multicolumn{2}{c}{ \% Specific ${ }^{\text {s1 } C r-\text {-release }}$} \\
\cline { 2 - 3 } & \multicolumn{2}{c}{ Pretreatment with } \\
\cline { 2 - 3 } Addition to endothelial monolayer & \multicolumn{1}{c}{ Ethanol control } & \multicolumn{1}{c}{ BCNU } \\
\hline A Bovine pulmonary artery & & $0.2 \pm 0.1$ \\
PMN (8) & $0.1 \pm 0.1$ & $15.1 \pm 2.2$ \\
PMN + PMA (8) & $0.4 \pm 0.1$ & $0.3 \pm 0.2$ \\
PMN + PMA + catalase (8) & $0.1 \pm 0.1$ & \\
B Human umbilical vein & & $3.4 \pm 0.1$ \\
PMN (6) & $4.6 \pm 0.1$ & $19.6 \pm 2.3$ \\
PMN + PMA (6) & $5.8 \pm 0.1$ & $2.9 \pm 0.2$ \\
PMN + PMA + catalase (6) & $0.9 \pm 0.1$ &
\end{tabular}

${ }^{51} \mathrm{Cr}$-labeled bovine pulmonary artery $(A)$, or human umbilical vein $(B)$ endothelial cell monolayers were preincubated for $10 \mathrm{~min}$ with BCNU $(100 \mu \mathrm{g} / \mathrm{ml})$ or ethanol control $(0.1 \%) .50 \mu \mathrm{l}$ of purified human neutrophils (PMN) in 10\% NBCS in Waymouth's medium was then added, followed by $50 \mu \mathrm{l}$ of medium with or without PMA (10 $\mathrm{ng} / \mathrm{ml}$ final). The neutrophil to endothelial cell ratio was $\sim 25: 1$. Catalase $(3,000 \mathrm{U} / \mathrm{ml})$ was added to PMN before the addition of PMA. $50 \mu \mathrm{l}$ of cell-free supernatant medium was aspirated after $6 \mathrm{~h}$ of incubation for determination of specific ${ }^{51} \mathrm{Cr}$-release. Values represent the means of $(n)$ replicates $\pm 1 \mathrm{SE}$.

some endogenous endothelial protective mechanism against neutrophil-mediated oxidant injury (25). The observations of Nathan et al. (1) and Arrick et al. (8) that tumor cell susceptibility to lysis by neutrophil-generated $\mathrm{H}_{2} \mathrm{O}_{2}$ depended on endogenous glutathione reductase activity and glutathione levels suggested to us that the glutathione redox cycle might also be an important antioxidant defense mechanism in cultured endothelial cells and could account, in part, for our failure to detect endothelial cell lysis by activated neutrophils. Moreover, the glutathione

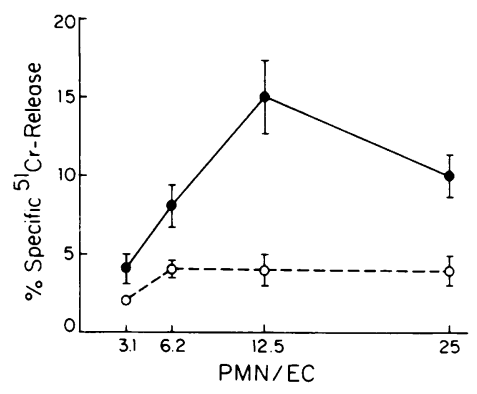

Figure 11. Effect of BSO on human endothelial ${ }^{51} \mathrm{Cr}$ release induced by PMAactivated neutrophils. Human umbilical vein endothelial cells were labeled overnight with ${ }^{51} \mathrm{Cr}$ in $10 \%$ NBCS in Waymouth's medium with $(\bullet)$ or without (o) BSO (1 mM). The cells were then washed and 50 $\mu \mathrm{l}$ of purified human pe-

ripheral blood neutrophils in 10\% NBCS in Waymouth's medium was added at varying neutrophil (PMN) to endothelial cell (EC) ratios followed by $50 \mu \mathrm{l}$ of PMA $(50 \mathrm{ng} / \mathrm{ml}$ final). After $6 \mathrm{~h}$, aliquots of cell-free supernatant medium were aspirated for determination of specific ${ }^{51} \mathrm{Cr}$-release. Values represent means of six replicates $\pm 1 \mathrm{SE}$. 
redox cycle may be important in preventing oxidant injury by other agents in addition to neutrophils.

The experiments presented in this report demonstrate that several strains of bovine aortic, bovine pulmonary artery, and human umbilical vein endothelial cells are relatively resistant to lysis by exogenously generated $\mathrm{H}_{2} \mathrm{O}_{2}$. If the glutathione redox cycle is disrupted by selective inhibition of endogenous glutathione reductase by $\mathrm{BCNU}$, however, then enzymatically generated $\mathrm{H}_{2} \mathrm{O}_{2}$ can induce endothelial cell lysis in a dose-dependent manner. Both glucose-glucose oxidase- and xanthine-xanthine oxidase- mediated lysis were catalase-inhibitable, indicating that $\mathrm{H}_{2} \mathrm{O}_{2}$ or a $\mathrm{H}_{2} \mathrm{O}_{2}$-derived product was the actual mediator of cell lysis, as has been previously demonstrated in cultured endothelial cells $(23,24,26)$.

The sensitivity of endothelial cell strains to $\mathrm{H}_{2} \mathrm{O}_{2}$-mediated lysis varied. Some human umbilical vein endothelial cell isolates were more readily lysed by glucose-glucose oxidase than others. Bovine endothelial cell strains also varied in their sensitivity to lysis by exogenously generated $\mathrm{H}_{2} \mathrm{O}_{2}$. For example, at the same concentration of glucose oxidase, significant lysis was observed in a strain of bovine aortic cells, whereas a strain of bovine pulmonary artery cells was unaffected (Table I). Although it is tempting to speculate that susceptibility to oxidant lysis might vary in endothelial cells derived from different vascular sites, it is important to consider that differences in sensitivity to $\mathrm{H}_{2} \mathrm{O}_{2}$ mediated injury in cultured endothelial cells might represent interanimal variation or result from repeated passage. These questions can be resolved only by comparing endothelial cells derived from different vascular sites in the same animal at similar passage.

The time course of $\mathrm{H}_{2} \mathrm{O}_{2}$-mediated endothelial lysis indicates that ${ }^{51} \mathrm{Cr}$-release is a relatively late event $(5-6 \mathrm{~h})$ in control cells and that lysis occurs earlier (3-4 h) when the glutathione redox cycle is disrupted by BCNU. Despite the fact that significant cell lysis was not observed after $2 \mathrm{~h}$ of incubation with glucoseglucose oxidase even in $\mathrm{BCNU}$-treated cells, significant ${ }^{51} \mathrm{Cr}$ release was still noted at $6 \mathrm{~h}$ in cells exposed to the $\mathrm{H}_{2} \mathrm{O}_{2}$ generating system for only $2 \mathrm{~h}$ before the addition of catalase. This suggests that a lethal event may occur relatively early during exposure to enzymatically generated $\mathrm{H}_{2} \mathrm{O}_{2}$, but that it requires several hours to become manifest as ${ }^{51} \mathrm{Cr}$-release.

It seems unlikely that $\mathrm{BCNU}$ potentiation of $\mathrm{H}_{2} \mathrm{O}_{2}$-mediated endothelial cell lysis represents a nonspecific effect rather than selective inhibition of the glutathione redox cycle. BCNU pretreatment did not increase bovine endothelial cell susceptibility to lysis by nonoxidant toxic agents including distilled water, calcium ionophore, or LPS. Moreover, BCNU pretreatment did not potentiate lysis by reagent hypochlorous acid, a potent oxidizing agent generated by the myeloperoxidase system in neutrophils (27), whereas lysis by reagent $\mathrm{H}_{2} \mathrm{O}_{2}$ was markedly enhanced in the same cells.

Further evidence that the glutathione redox cycle is specifically involved in protecting cultured endothelial cells against $\mathrm{H}_{2} \mathrm{O}_{2}$-mediated lysis is provided by the observation that depletion of cellular stores of reduced glutathione by reaction with the electrophilic reagents DEM and CDNB and by inhibition of glutathione synthesis with BSO also increased endothelial cell susceptibility to lysis by extracellularly generated $\mathrm{H}_{2} \mathrm{O}_{2}$.

Even prolonged exposure to PMA-activated neutrophils did not produce significant lysis of control bovine and human endothelial cell monolayers at $6 \mathrm{~h}$. Resistance to lysis by PMAactivated neutrophils in our assay appeared to be due, at least in part, to detoxification of $\mathrm{H}_{2} \mathrm{O}_{2}$ by the glutathione redox cycle, since significant catalase-inhibitable ${ }^{51} \mathrm{Cr}$-release was observed when BSO- or BCNU-treated endothelial cells were exposed to PMA-activated neutrophils. Since $\mathrm{H}_{2} \mathrm{O}_{2}$ production by neutrophils occurs primarily during an initial burst, the ${ }^{51} \mathrm{Cr}$-release observed at $6 \mathrm{~h}$ in BCNU- or BSO-treated cells following incubation with PMA-activated neutrophils may be analogous to the ${ }^{51} \mathrm{Cr}$-release noted at $6 \mathrm{~h}$ after addition of catalase to the glucose-glucose oxidase system at 1.5-2 $\mathrm{h}$.

These studies demonstrate that interruption of one of the major endogenous antioxidant mechanisms, the glutathione redox cycle, significantly increases endothelial cell susceptibility to lysis by $\mathrm{H}_{2} \mathrm{O}_{2}$ in vitro. The fact that disruption of the glutathione redox cycle potentiated $\mathrm{H}_{2} \mathrm{O}_{2}$-mediated lysis in primary passage human umbilical vein endothelial cells as well as the multiply passaged bovine aortic and pulmonary artery endothelial cells suggests that the glutathione redox cycle is a common mechanism for detoxifying $\mathrm{H}_{2} \mathrm{O}_{2}$ in cultured endothelial cells. Further studies are required to determine the relative importance of endogenous catalase and whether simultaneous inhibition of catalase and the glutathione redox cycle would further increase endothelial susceptibility to lysis by enzymatically or neutrophilgenerated $\mathrm{H}_{2} \mathrm{O}_{2}$.

Differences in levels of endogenous antioxidant enzymes in cultured endothelial cells may account for some of the discrepancies in experimental results observed in oxidant injury models in vitro $(16,23-26)$. More importantly, since the endothelium may frequently be exposed to oxygen products generated by inflammatory cells, toxic agents, or hyperoxia, endogenous antioxidant mechanisms such as the glutathione redox cycle may be critical in preventing or limiting vascular injury in vivo. (28)

\section{Acknowledgments}

We gratefully acknowledge the technical assistance of Kathe Stanness at Harborview Medical Center and Linda Forman at Scripps Clinic and Research Foundation and the nursing staffs of the Obstetrical Units of Swedish and Group Health Hospitals for providing umbilical cords for the culture of human endothelial cells.

This work was supported in part by research grants GM 29853, HL 07312, HL 18645, and HL 29036 from the U. S. Public Health Service and a grant from R. J. Reynolds Industries, Inc.

\section{References}

1. Nathan, C. F., B. A. Arrick, H. W. Murray, N. M. DeSantis, and Z. A. Cohn. 1981. Tumor cell anti-oxidant defenses. Inhibition of the 
glutathione redox cycle enhances macrophage-mediated cytolysis. J. Exp. Med. 153:766-782.

2. Beutler, E. 1971. Abnormalities of the hexose monophosphate shunt. Semin. Hematol. 8:311-347.

3. Roos, D., R. S. Weening, A. A. Voetman, M. L. van Schaik, A. A. Bot, L. J. Meerhorf, and J. A. Loos. 1979. Protection of phagocytic leukocytes by endogenous glutathione: studies in a family with glutathione reductase deficiency. Blood. 53:851-866.

4. Meister, A. 1983. Selective modification of glutathione metabolism. Science (Wash. DC). 220:472-477.

5. Frischer, H., and T. Ahmad. 1977. Severe generalized glutathione reductase deficiency after antitumor chemotherapy with BCNU $(1,3-$ bis(chloroethyl)-1-nitrosourea). J. Lab. Clin. Med. 89:1080-1091.

6. Babson, J. R., and D. J. Reed. 1978. Inactivation of glutathione reductase by 2-chloroethyl nitrosourea-derived isocyanates. Biochem. Biophys. Res. Commun. 83:754-762.

7. Novogrodsky, A., R. E. Nehring, Jr., and A. Meister. 1979. Inhibition of amino acid transport into lymphoid cells by the glutamine analog L-2-amino-4-oxo-5-chloropentanoate. Proc. Natl. Acad. Sci. USA. 76:4932-4935.

8. Arrick, B. A., C. F. Nathan, O. W. Griffith, and Z. A. Cohn. 1982. Glutathione depletion sensitizes tumor cells to oxidative cytolysis. J. Biol. Chem. 257:1231-1237.

9. Chasseaud, L. F. 1979. The role of glutathione and glutathioneS-transferases in the metabolism of chemical carcinogens and other electrophilic agents. Adv. Cancer Res. 29:175-274.

10. Wedner, H. J., L. Simchowitz, W. F. Stenson, and C. M. Fischman. 1981. Inhibition of human polymorphonuclear leukocyte function by 2-cyclohexene-1-one. A role for glutathione in cell activation. J. Clin. Invest. 68:535-543.

11. Mitchell, J. B., A. Russo, T. J. Kinsella, and E. Glatstein. 1983. Glutathione elevation during thermotolerance induction and thermosensitization by glutathione depletion. Cancer Res. 43:987-991.

12. Griffith, O. W., and A. Meister. 1979. Potent and specific inhibition of glutathione synthesis by buthionine sulfoximine ( $S$-n-butyl homocysteine sulfoximine). J. Biol. Chem. 254:7558-7560.

13. Schwartz, S. M. 1978. Selection and characterization of bovine aortic endothelial cells. In Vitro (Gaithersburg). 14:966-980.

14. Wall, R. T., L. A. Harker, L. J. Qaudracci, and G. E. Striker 1978. Factors influencing endothelial cell proliferation in vitro. J. Cell. Physiol. 96:203-213.
15. Boyum, A. 1968. Isolation of mononuclear cells and granulocytes from human blood. Isolation of mononuclear cells by one centrifugation, and of granulocytes by combining centrifugation and sedimentation at 1 g. Scand. J. Clin. Lab. Invest. 21(Suppl. 97):77-89.

16. Harlan, J. M., P. D. Killen, L. A. Harker, and G. E. Striker. 1981. Neutrophil-mediated endothelial injury in vitro. Mechanisms of cell detachment. J. Clin. Invest. 68:1394-1403.

17. Beutler, E. 1975. Red Cell Metabolism. A Manual of Biochemical Methods. Grune \& Stratton, Inc., New York. 69-70, 89-90.

18. Mendelson, D. S., E. N. Metz, and A. L. Sagone, Jr. 1977. Effect of phagocytosis on the reduced soluble sulfhydryl content of human granulocytes. Blood. 50:1023-1030.

19. Vogt, M. T., C. Thomas, C. L. Vassallo, R. E. Basford, and J. B. L. Gee. 1971. Glutathione-dependent peroxidative metabolism in the alveolar macrophage. J. Clin. Invest. 50:401-410.

20. Beutler, E., O. Duron, and B. M. Kelly. 1963. Improved method for the determination of blood glutathione. J. Lab. Clin. Med. 61:882888.

21. Harrison, J. E., and J. Schultz. 1976. Studies on the chlorinating activity of myeloperoxidase. J. Biol. Chem. 251:1371-1374.

22. Kosower, N. S., and E. M. Kosower. 1978. The glutathione status of cells. Int. Rev. Cytol. 58:109-160.

23. Sacks, T., C. F. Moldow, P. R. Craddock, T. K. Bowers, and H. S. Jacob. 1978. Oxygen radicals mediate endothelial cell damage by complement-stimulated granulocytes. An in vitro model of immune vascular damage. J. Clin. Invest. 61:1161-1167.

24. Weiss, S. J., J. Young, A. F. LoBuglio, A. Slivka, and N. F. Nimeh. 1981. Role of hydrogen peroxide in neutrophil-mediated destruction of cultured endothelial cells. J. Clin. Invest. 68:714-721.

25. Hoover, R. L., J. M. Robinson, and M. J. Karnovsky. 1982. Superoxide production by polymorphonuclear leukocytes is inhibited by contact with endothelial cells. J. Cell Biol. 95:37a. (Abstr.)

26. Suttorp, N., and L. M. Simon. 1982. Lung cell oxidant injury. Enhancement of polymorphonuclear leukocyte-mediated cytotoxicity in lung cells exposed to sustained in vitro hyperoxia. J. Clin. Invest. 70:342-350.

27. Klebanoff, S. J. 1980. Oxygen metabolism and the toxic properties of phagocytes. Ann. Intern. Med. 93:480-489.

28. Frank, L., J. Summerville, and D. Massaro. 1980. Protection from oxygen toxicity with endotoxin. Role of the endogenous antioxidant enzymes of the lung. J. Clin. Invest. 65:1104-1110. 